\author{
ANDRZEJ WRÓBEL \\ Kognitywistyka \\ Instytut Filozofii \\ Uniwersytet Warszawski \\ Krakowskie Przedmieście 3, 00-927 Warszawa \\ e-mail: andrzej.wrobel@uw.edu.pl
}

\title{
JAK POWSTAJE UMYSŁ - WSPÓŁCZESNE BADANIA NEUROBIOLOGICZNE MÓZGU - WSTEP
}

Badania neurobiologiczne mózgu to obecnie najbardziej dynamicznie rozwijajaca się dziedzina nauki. W krajach rozwiniętych duże nakłady na te badania sa bezpośrednio zwiazane $z$ rosnacymi lawinowo kosztami opieki medycznej nad pacjentami z zaburzeniami neurologicznymi i psychiatrycznymi. Wynika to ze starzenia się społeczeństw, jak również ze wzrastającego wpływu czynników stresujacych, związanych $z$ życiem codziennym. Pomimo wzrostu zainteresowania neuronaukami, aż dwie dekady upłynęły od publikacji poprzedniego numeru KOSMOSU poświęconego w całości metodom badania mózgu. Tom Zobaczyć myśl (46/3, 1997), przygotowany przez A. Wróbla i S. Kasickiego, okazał się dużym sukcesem - jest do dziś cytowany i czytany przez studentów nowopowstajacych kierunków studiów neurobiologicznych i kognitywistycznych. Od tego czasu zmieniła się jednak nie tylko metodyka badań, ale znacznie poszerzył się również zakres zainteresowań neuronauk.

W bieżacym numerze przedstawiamy współczesne techniki używane w neurobiologii, neurofizjologii, neurologii i psychiatrii, oraz (daleko niekompletny) wybór nowych, goracych tematów neuronauki światowej. Tematy te przybliżaja mechanizmy fizjolo- giczne i źródła patologii działania mózgu, od poziomu molekularnego przez aktywność neuronów i systemów neuronalnych, do badań kognitywistycznych umysłu i modelowania metodami neuroinformatyki. Artykuły do tego numeru zgodzili się napisać młodzi badacze, przedstawiciele najlepszych krajowych laboratoriów i polscy naukowcy pracujacy w ośrodkach zagranicznych. Zbiór ten jest poprzedzony naukowym biogramem prof. Jerzego Konorskiego, założyciela współczesnej polskiej szkoły neuronaukowej, wieloletniego Kierownika Zakładu Neurofizjologii i Dyrektora Instytutu Nenckiego w Warszawie.

Tom ten jest kierowany przede wszystkim do studentów i doktorantów kierunków neurobiologicznych i kognitywistycznych na uniwersytetach i akademiach medycznych, ale powinien być atrakcyjny również dla wszystkich czytelników zainteresowanych obecnym stanem nauk o mózgu na świecie.

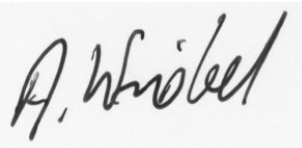

